\title{
MODERN CHALLENGES IN THE DEVELOPMENT OF TOURISM IN RURAL AREAS
}

\author{
Agata Balińska, $\mathrm{PhD}^{1}$; Anna Sieczko, Eng $\mathrm{PhD}^{2}$; Jan Zawadka, $\mathrm{PhD}^{3}$; \\ Piotr Gabryjończyk, MSc ${ }^{4}$
}

Faculty of Economic Sciences, Warsaw University of Life Sciences - SGGW

\begin{abstract}
The purpose of the article is to indicate the most important challenges for the development of rural tourism in Poland. Attention is also paid to the research problems in the field of the studied issues identified during the scientific activity of employees of the Division of Tourism and Country Development, Faculty of Economic Sciences at Warsaw University of Life Sciences - SGGW. The research method was the analysis of scientific articles published by the employees of the Department. The complexity of the issue of exploring the demand and supply side of rural tourism was indicated. Also, the most interesting or symptomatic elements for the further development of the scale and character of the described phenomenon were noted. In the forefront are the changes postulated by demand, forcing specific reactions accommodation providers. Therefore, there is a need to adjust supply side support to implement solutions that meet the expectations of tourists.
\end{abstract}

Keywords: agritourism, rural areas, development

JEL codes: Z32, L83

\section{INTRODUCTION}

Rural tourism as a socio-economic category is intensively changing. Modifications can be noticed on both the tourist demand and supply side. The need to improve the tourism offer is affected not only by changes in demand, but also by legal and financial regulations, the profitability of agricultural production, as well as the evolution of human capital in rural areas and many other factors. The diversity of conditions for the development of rural tourism and the multifaceted and multidimensional nature of the effects of this development create a broad and interesting field of scientific inquiry. Research in this area has been carried out by employees of the Division of Tourism and Country Development since 1998 and has resulted in many dissertations and scientific publications. The purpose of the article was to discuss selected challenges for the development of rural tourism in Poland, such as the legal basis and financial issues, changes in the offer of rural tourism and improvement of its quality, as well as advice and information. To fulfill this task, the authors used their own scientific achievements in this area and made

\footnotetext{
${ }^{1}$ Corresponding author: Nowoursynowska 166,02-787 Warsaw, Poland, agata_balinska@sggw.pl

${ }^{2}$ Corresponding author: Nowoursynowska 166,02-787 Warsaw, Poland, anna_sieczko@sggw.pl

${ }^{3}$ Corresponding author: Nowoursynowska 166, 02-787 Warsaw, Poland, jan_zawadka@sggw.pl, +4822 5934154

${ }^{4}$ Corresponding author: Nowoursynowska 166,02-787 Warsaw, Poland, piotr_gabryjonczyk@sggw.pl, +4822 5934158
} 
an attempt to synthetically analyse the main research problems, like changes in tourism offers, consultancy, information, legal bases and finances as important factors for the development of this form of non-agricultural activity and quality improvement, which is an answer to the change of needs of people spending their holidays in the countryside.

\section{ADVISORY AND INFORMATIONAL CONDITIONS FOR THE DEVELOPMENT OF RURAL TOURISM}

There are many determinants of the development of rural tourism. Literature of the subject gives, among others, natural and anthropogenic assets, technical, utilitarian and functional qualities, tourist preferences etc. (Sikorska-Wolak, 2008; Zawadka, 2010c). Moreover, two more determinants are worth noting: knowledge necessary to take on new challenges and information affecting economic activities undertaken by owners of agritourism farms. Initiators and pioneers of activities in both information and knowledge in Poland, were agricultural advisory centres (ODR). Regarding agritourism, support provided by advisers included (Parzonko and Sieczko, 2007):

- access to current information and knowledge through participation in various forms of education organized for owners of tourist facilities (trainings, courses, seminars, conferences, study trips),

- adaptation of farms to provide tourist services in accordance with legal requirements (especially agritourism),

- creation of tourist products and offers for spending free time,

- organization of competitions for owners of rural tourism facilities,

- promotion of offers of owners cooperating with ODR (by using the website of the centres, participating in outdoor events, fairs and exhibitions).

Rural tourism facilities are subject to the laws of the market in the same manner as other entities operating in the tourism industry. However, nowadays the matter is all the more complicated because surviving on the market is not enough - enterprises must adapt their offers to the constantly changing needs of customers. In addition to ODRs, market information necessary to conduct tourist activities in the countryside can also be obtained from other sources, i.e. (Balińska, Sieczko and Zawadka, 2014):

- statistical data (statistics of the Institute of Tourism, reports of the Central Statistical Office (CSO), studies of the Ministry of Agriculture and Rural Development and the Ministry of Sport and Tourism),

- analysis of trends in tourism markets,

- forecasts for tourism markets,

- forecasts regarding required qualifications in particular service activities of tourism enterprises.

The employees of the Division of Tourism and Country Development, as part of their scientific research, have often addressed problems related to the broadly understood agritourism information. Publications covering the supply and demand side of the domestic tourism market have allowed to formulate and signal the following issues.

1. Tourists using tourist facilities located in the countryside were looking for the following elements of service: peace and quiet, the possibility of active recreation, nature, affordable prices, learning about rural life, healthy food and cultural events. What is interesting, accommodation providers do not necessarily concentrate their activity near the most valuable and legally protected natural areas (like National Parks or preserves), the presence of which is often referred to as a factor determining the development of rural tourism and tourist preferences (Sikora, 1999; Sikorska-Wolak, 2009). It turns out that farm owners are most likely to operate in the vicinity of areas that are not subject to restrictive regulations and restrictions on the possibility of tourist penetration, such as landscape parks and areas of protected landscape (Gabryjończyk and Kułaga, 2017). From the tourist's point of view, the factor with a significant impact on the choice of a particular agritourism farm was the distance from their place of residence. A private bathroom also had crucial meaning. Furthermore, the recreational space around the house was important, as well as meals based on organic products, access to sports equipment, the possibility of arrival with a pet and opportunity for learn- 
ing arts and crafts (Sikorska-Wolak and Zawadka, 2012a; Balińska, 2014; Sieczko, 2016).

2. Tourists consider the Internet to be the most important source of information about the tourist offer. However, information available there was not satisfactory. Access to information was hindered by the necessity of phoning the owner for more details concerning the offer yet relevant to the consumer. It was also indicated that the information presented on national internet portals was too general and did not contain a full database of offers. Although consumers had the possibility to choose offers in terms of region/province or the ability to filter by object, a more advanced search, based on categorized features of tourist propositions, was difficult (e.g. it was not possible to look for an individual bathroom or specific food, like ecological or regional). Difficulties also resulted from the content - descriptions of individual offers were too long and non-distinctive, therefore inconvenient in reception. There were also no tools to facilitate price comparisons or offers in terms of prices (Sikorska-Wolak and Zawadka, 2012b; Sieczko, 2015).

\section{LEGAL AND FINANCIAL ASPECTS OF STARTING AND RUNNING AGRITOURISM ACTIVITY}

Reflections on the legal and financial aspects of rural tourism, including agritourism, are hindered by a lack of official definition of these concepts. The definition of agritourism is the most doubtful - by most researchers, it is identified with the form of rural tourism closely related to a functioning farm. Some light on this issue is cast by the $\mathrm{CSO}$, which defines the agritourism lodging, while an agritourism farm is a farm on which tourism activity is conducted next to agricultural activity (Zawadka, 2010b).

One of the most important clauses regulating the conduct of tourist activities by farmers is the 2 nd paragraph of the 3rd article of the Act of the 2 July 2004, on the freedom of economic activity, where it was stated that the regulations of this Act do not apply in the case of farmers renting rooms, selling homemade meals or providing other services related to the stay of tourists on farms. According to this clause, farmers hosting tourists are not treated as entrepreneurs, which is of great importance in the case of formalities related to the start-up of this type of nonagricultural activity. The farmer is naturally obliged to maintain several formalities, including the duty to report the place to the record kept by the community mayor, meeting the minimal requirements for equipment, as well as sanitary, fire and other needs set out in separate regulations. What is important, he does not need to register his venture as an enterprise. This fact results, among others, in tax obligations. Under certain conditions, a farmer conducting tourist activity may be relieved from the obligation to pay income tax on this account.

However, many hosts, along with the development of their agritourism activity, decide to register it as a normal business. This allows, among others, for the employment of workers or provision of additional tourist services (e.g. organization of tourist events, rental of bicycles, canoes, boats, etc.) or services based on land and buildings unrelated to the farm (Sztorc, 2009).

An inseparable part of any activity, including tourism, is obtaining and allocating a certain amount of money for start-up. Such financing may have various sources. In the case of agritourism, own savings are most often used, and the amount of money invested in the preparation of the facility for receiving guests usually does not exceed several thousand PLN (Zawadka, 2010a, b; Balińska, 2016). Farmers planning more serious investment in the field of rural tourism, in addition to their own savings, can take advantage of several other options. The most attractive one seems to be funds from the European Union, distributed under the Rural Development Programme for 2014-2020. Funds for starting and developing projects in the field of rural tourism and agritourism can be obtained through Priority 6: 'Promoting social inclusion, poverty reduction and economic development in rural areas'. Activities under this, as well as other priorities, will be implemented (as in RDP 2007-2013) thanks to the European Agricultural Fund for Rural Development (EAFRD). Under the 6th priority of RDP 2014-2020, support for rural tourism can be implemented through three activities: Basic services and village renewal in ru- 
ral areas (M07), Support for local development under the LEADER initiative (M19), as well as Farm and business development (M06). In this last one, the sub-measure Aid for starting non-agricultural business activity in rural areas - Bonus for starting non-agricultural activity (6.2) deserves particular attention. As the name suggests, assistance is provided in the form of bonuses (in two installments), not on the principle (often dubious and incomplete) of the reimbursement of costs incurred to start a given activity, as was the case in RDP 2007-2013. The maximum amount of support for a single venture is PLN 100,000 , and a farmer, farmer's wife or farmer's household (who, among others, should be subject to social insurance for farmers) can apply for help. It should be emphasized here that the support relates to economic activity - the beneficiary is obliged to set up an enterprise. As part of the discussed activity, projects in the field of craft or handicraft may also be supported.

In addition to funds from the EU, as potential sources of financing the development of economic activity related to tourism in rural areas, SME Loans offered by the European Fund for the Development of Polish Villages, as well as Micro-loans of the Rural Development Foundation should be specified. Their advantage is a relatively low interest rate.

It is worth mentioning here that practically all financial support instruments offered to rural residents and aimed at the development of rural tourism and agritourism are intended for people running a business or for those who will ultimately become entrepreneurs. Currently, there is no support for farmers who want to establish or develop agritourism without transforming it into a business. The exception is preferential loans, however their availability is not constant and conditions of obtaining them are often modified.

It should be emphasized that the research carried out by the employees of the Division of Tourism and Country Development prove that knowledge in the field of legal regulations and economic analysis is desired by rural accommodation providers to a lesser extent than knowledge of a regions' tourist assets. These regulations are perceived as a significant barrier to the development of tourist activities but, at the same time, farmers demonstrate the need for training in this field (Balińska, 2016).

\section{QUALITY IMPROVEMENT AND DIVERSIFICATION OF THE TOURIST OFFER IN RURAL AREAS}

Changes in consumer expectations and needs are increasingly related to improving the quality of services. Quality is defined as 'the sum of product or service characteristics crucial for the ability of a given product to meet specific needs' (Kotler, 1994). Such quality can be understood as technical, which in the case of tourism primarily includes the standard of equipment of facilities, their technical condition, or abstract - it contains elements related to the aesthetics of the object, but also the personality traits of the service provider. Elements that create technical quality are subject to standardization through a system of categorizing hotel facilities and, in the case of rural tourism facilities, the system of categorizing rural accommodation base (SCRAB). While the categorization of hotel facilities is obligatory and identified by clients, SCRAB is voluntary and very poorly positioned in the minds of consumers and accommodation providers. This was confirmed by research conducted by employees of the Division of Tourism and Country Development. According to Balińska's research carried out in 2012, among 160 owners of rural tourism facilities located in communities along the eastern Polish border, only $4.4 \%$ of accommodation providers subjected their facilities to assessment under this system, and another $11.3 \%$ knew it and planned to do so. Almost every fourth (23.1\%) respondent did not know this system, which confirms its low positioning not only when it comes to awareness of consumers, but also service providers. Over half (55\%) were familiar with the system, however did not plan to use it. Another $3.8 \%$ of respondents subjected their facilities to assessment in the past, but failed to notice any benefits and gave up on the system. Only $12.5 \%$ of respondents felt that the aforementioned system improves the competitiveness of rural tourism facilities because it guarantees a certain standard and helps in promotion (Balińska, 2016). Zawadka's research conducted among rural accommodation providers in 
the Lubelskie province proved that only $29.6 \%$ of farms covered by the study were categorized (Zawadka, 2010c). This author's research carried out among tourists presents that the awareness of the existence of categorization is very low (only $8.6 \%$ of the total 830 respondents), and only $3.9 \%$ of respondents were able to indicate correctly the symbol, which illustrates the category in SCRAB (Zawadka, 2017). Also Balińska's research, conducted among tourists, using agritourism farms, showed that only for $15.5 \%$ of respondents, categorization was the leading factor in the selection of the facility (Balińska, 2014) .

Improving the quality of services, in this case tourist services, requires cyclical research on customer needs and their level of satisfaction. Differentiation of research methods is beneficial in this case (Balińska, 2015a, b, c).

In addition to improving the quality of tourist services, an important direction of changes is the thematic differentiation of holiday offers in the countryside. The main themes are:

- ecotourism realized on certified organic farms,

- cultural tourism, using cultural assets of the region, forms of which include culinary tourism, based on food raw materials, dishes, preserves or liquors (enotourism, birotourism), and military tourism,

- active tourism, including riding and cycling.

A particularly interesting case in this group is military tourism, which was noted by Sikora, who included historical sites, such as battlefields and military objects, to the elements of the cultural landscape of the countryside (Sikora, 2012). Twentieth-century military constructions, usually located in non-urbanized areas (forest or rural), constitute an original diversity of the traditional heritage of the country. This was confirmed in Gabryjończyk's research, conducted in 2012, in selected post-military objects of Eastern Poland, which proved that the majority (even 90\%) of tourists perceive such places as attractive, positively distinguishable among other tourist assets present in communities, and constituting a factor determining a respondent's will to visit a given area in one-third
(Gabryjończyk, 2013, 2014). Military facilities can become objects attracting tens of thousands of people per year, spending significant amounts of money during their visits, however only under special circumstances: the preparation of a suitable, rich offer and infrastructure necessary to meet the expectations of visitors (Gabryjończyk, 2012). Unfortunately, the barriers to such activities are often financial and legal issues, effectively discouraging rural residents to take more extensive action in the field of tourist adaptation of post-military constructions.

\section{CONCLUSIONS}

The issues presented in the text are only a part of the problem of contemporary tourism development in rural areas. Nevertheless, they were considered by the authors as the most interesting or symptomatic for the further evolution of the scale and nature of this phenomenon. Therefore, on the basis of the presented considerations, several conclusions can be formulated:

- the term 'agritourism' has not been defined in any normative act to this day,

- the legal treatment of farmer activity organizing tourism on own farms as non-economic and tax free is a significant facilitation for accommodation providers,

- starting agritourism activity is not associated with large investment, therefore these expenses are usually covered by a farmer's own savings; potential sources like EU funds are not very popular in this case,

- Agricultural Advisory Centres have significantly contributed to the development of rural tourism in Poland; their support in the area of tourist knowledge and information was especially addressed to owners of agritourism farms,

- tourists using rural tourism facilities are mainly looking for peace and quiet, the possibility of active rest in natural surroundings, affordable prices, an occasion to learn about rural life, healthy food and participation in cultural events,

${ }^{5}$ The research was conducted on a sample of 400 respondents in 2012. 
- the most effective information tool is the internet, despite not being very precise, in depth, intuitive or sometimes even difficult to find information published by farm owners,

- leisure offers within rural tourism are characterized by very large diversity; both the owners of service facilities and local authorities are taking action to promote offers that have not yet been exposed, but can potentially attract tourists, such as culinary or military facilities,

- there is a significant disproportion between the expectations of tourists and the image of farm owners in terms of the quality of provided services; the currently functioning system of categorizing rural accommodation base does not fulfil its functions.

\section{REFERENCES}

1. Balińska, A. (2014). Determinanty popytu mieszkańców Warszawy na usługi agroturystyczne [Determinants of the demand of the inhabitants of Warsaw for agritourism services]. Ekonomiczne Problemy Turystyki, 805 (25), pp. 251-264.

2. Balińska, A. (2015a). Możliwości wykorzystania metody SERVQUAL w poprawie konkurencyjności oferty agroturystycznej dla studentów [Possibilities of using the SERVQUAL method in improving the competitiveness of agrotourism offer for students]. Studia Komitetu Przestrzennego Zagospodarowania Kraju PAN, 163, pp. 194-206.

3. Balińska, A. (2015b). The impact of quality management system on the selection of travel companies' offers. Management: Science and Education: Slovak Scientific Journal, 4 (2), pp. 5-8.

4. Balińska, A. (2015c). The role of the customer in creating the quality of tourism services. In: Mazurek-Kusiak, A. (ed.) Managing the quality of tourism services. Uniwersytet Przyrodniczy w Lublinie, Lublin, pp. 408$-416$.

5. Balińska, A. (2016). Znaczenie turystyki w rozwoju gmin wiejskich na przykładzie obszarów peryferyjnych wschodniego pogranicza Polski [The importance of tourism in the development of rural communes on the example of peripheral areas of the eastern border of Poland]. Wydawnictwo SGGW, Warszawa.

6. Balińska, A., Sieczko, A., Zawadka, J. (2014). Turystyka. Wybrane zagadnienia [Tourism. Selected issues]. Difin, Warszawa.
7. Gabryjończyk, P. (2012). Struktura wydatków osób zwiedzających zabytki militarne (na przykładzie Wilczego Szańca w Gierłoży) [Structure of sightseers' expenses in military tourist attractions: the case of Wolf's Lair in Gierłoż]. Zeszyty Naukowe SGGW w Warszawie. Ekonomika i Organizacja Gospodarki Żywnościowej, 100, pp. 107-119.

8. Gabryjończyk, P. (2013). The role of historical fortifications in creating touristic competitiveness of rural areas on example of tourist route 'Kwatera Dowodzenia' in Cieszyna-Stępina. In: Krzyżanowska, K. (ed.) Creating competitiveness of Polish and Ukrainian rural areas. Wydawnictwo SGGW, Warszawa, pp. 61-71.

9. Gabryjończyk, P. (2014). „Skansen Fortyfikacji Prus Wschodnich" jako szansa rozwoju turystycznego gminy Bakałarzewo ['Museum of East Prussia Fortifications' as an opportunity of tourist development of Bakałarzewo community]. Turystyka i Rozwój Regionalny, no. 1/2014, pp. 33-44.

10. Gabryjończyk, P., Kułaga, K. (2017). Relationship between agritourism lodgings and nature conservation in Eastern Region of Poland. Intercathedra, 33 (2), pp. 21-28.

11. Kotler, Ph. (1994). Marketing - Analiza, planowanie, wdrażanie i kontrola [Marketing - Analysis, planning, implementation and control]. Gebetner \& Spółka, Warszawa.

12. Parzonko, A.J., Sieczko, A. (2007). Doradztwo turystyczne w Polsce [Tourist consulting in Poland]. In: Sikorska-Wolak, I. (ed.) Turystyka w rozwoju obszarów wiejskich [Tourism in rural development]. Warszawa, pp. 392-393.

13. Sieczko, A. (2016). Informacja i promocja w agroturystyce [Information and promotion in agritourism]. In: Jęczmyk, A., J. Uglis, J., Macikowiak, M. (eds.) Turystyka wiejska. Zagadnienia ekonomiczne i marketingowe [Rural tourism. Economic and marketing issues]. Wieś Jutra, Poznań, pp.157-164.

14. Sieczko, A., Sieczko, L. (2015). Dostępność informacji o turystyce wiejskiej za pomocą nowoczesnych narzędzi IT [Access to information about rural tourism using modern IT tools]. Studia Komitetu Przestrzennego Zagospodarowania Kraju PAN, 163, pp. 167-177 .

15. Sikora, J. (1999). Organizacja ruchu turystycznego na wsi [Organization of tourism in the countryside]. WSiP, Warszawa.

16. Sikora, J. (2012). Agroturystyka. Przedsiębiorczość na obszarach wiejskich [Agritourism. Entrepreneurship in rural areas]. C.H. Beck, Warszawa. 
17. Sikorska-Wolak I. (2009). Kształtowanie funkcji turystycznych obszarów wiejskich - potrzeby i możliwości [Developing the tourist functions of rural areas - needs and possibilities]. In: Sikorska-Wolak, I. (ed.) Turystyczne funkcje obszarów wiejskich [Tourist functions of rural areas]. Wydawnictwo SGGW, Warszawa, p. 23.

18. Sikorska-Wolak, I. (ed.). (2008). Ekonomiczne i społeczne aspekty rozwoju turystyki wiejskiej [Economic and social aspects of the development of rural tourism]. Wydawnictwo SGGW, Warszawa.

19. Sikorska-Wolak, I., Zawadka, J. (2012a). Oczekiwania konsumentów na rynku usług agroturystycznych [Expectations of consumers in the market of agrotourism]. Studia Ekonomiczne i Regionalne, 5 (1), pp. 34-47.

20. Sikorska-Wolak, I., Zawadka, J. (2012b). Działania marketingowe gospodarstw agroturystycznych i ich ocena [Marketing activities of agritourism farms and their assessment. Zeszyty Naukowe Uniwersytetu Szczecińskiego. Ekonomiczne Problemy Usług, 705 (89), pp. 288-304.

21. Sztorc, I. (2009). Jak założyć gospodarstwo agroturystyczne [How to create an agritourism farm]. Ośrodek Promowania Przedsiębiorczości w Sandomierzu, Sandomierz.

22. Ustawa z dnia 2 lipca 2004 r. o swobodzie działalności gospodarczej [Act of 2 July 2004 on the freedom of economic activity]. Journal of Laws 2004 No 173 item 1807.
23. Zawadka, J. (2010a). Finansowanie i poziom zwrotu wydatków poniesionych na rozpoczęcie działalności agroturystycznej na Lubelszczyźnie [Financing and the level of reimbursement of expenses incurred for starting agritourist activity in the Lublin region]. Acta Scientiarum Polonorum. Oeconomia, 9 (2), pp. 241-249 .

24. Zawadka, J. (2010b). Ekonomiczno-społeczne determinanty rozwoju agroturystyki na Lubelszczyźnie (na przykładzie wybranych gmin wiejskich) [Economic and social determinants of agritourism development in the Lublin region (on the example of selected rural municipalities)]. Wydawnictwo SGGW, Warszawa.

25. Zawadka, J. (2010c). Determinanty rozwoju agroturystyki na przykładzie wybranych gmin wojewodztwa lubelskiego ]Determinants of agrotourism development on the example of selected municipalities of the Lublin province]. Roczniki Naukowe SERiA, 12 (5), pp. 275-280 .

26. Zawadka, J. (2015). Możliwości finansowania przedsięwzięć z zakresu turystyki wiejskiej w perspektywie 2014-2020 [Possibilities of financing projects in the field of rural tourism in the 2014-2020 perspective]. Studia Komitetu Przestrzennego Zagospodarowania Kraju PAN, 163, pp. 279-289.

27. Zawadka, J. (2017). Categorisation of rural accommodation facilities and its popularity among Polish citizens. Acta Scientiarum Polonorum. Oeconomia, 16 (1), pp. 101-109. 